\title{
A state of the art on the structural performance of fabric formwork systems
}

\author{
Farzaneh Tahmoorian $^{\mathrm{a}}$, Saeed Nemati ${ }^{\mathrm{b} *}$ and Anahita Soleimani ${ }^{\mathrm{c}}$
}

${ }^{a}$ School of Engineering and Technology, Central Queensland University, Australia

${ }^{b}$ World Civil Engineering Information Centre, Australia

${ }^{c}$ Dessau international architecture, Hochschule Anhalt University, Germany

\begin{tabular}{l}
\hline A R T I C L EI N F O \\
\hline Article history: \\
Received 8 July, 2019 \\
Accepted 22 August 2019 \\
Available online \\
22 August 2019 \\
\hline Keywords: \\
Fabric formwork \\
Flexible formwork \\
Durability \\
Structural aspects \\
Non-prismatic members
\end{tabular}
\begin{abstract}
A B S T R A C T
Fabric Formworks which are made using textile sheets such as Polyolefin, Polyesters/Polyethylene Terephthalate, nylon and Polypropylene are being used instead of conventional formworks in the construction industry. This article summarises significant studies and provides an updated review of references on the structural performance of fabric formworks over the last decade. The survey showed that they could be categorised into seven themes; namely, "Feasibility studies and manufacturing methods of complex structural elements"; "Finite element modelling, structural optimizing and form-finding themes"; "Pneumatic / Vacuumatic formwork theme"; "Durability, sustainability, efficiency and quality improvement"; "Cable-net fabric formwork theme"; "Stayin-place structural formworks theme"; and "Review papers". These categories comprise about $25 \%, 17 \%, 15 \%, 15 \%, 10 \%, 6 \%$ and $6 \%$ of related studies respectively.
\end{abstract}

(c) 2020 Growing Science Ltd. All rights reserved.

\section{Introduction}

Generally speaking, about $50 \%$ of the total cost of concrete structures is related to the formwork material and its system. Almost, all of the traditional formworks are made using rigid materials such as wood and steel. However, today, flexible formworks are being used instead of conventional formworks in building construction. Fabric formworks are the most common type of flexible formworks. Fabric Formwork is made using textile materials such as polyolefin, nylon, polyesters/polyethylene terephthalate (PET), and polypropylene (PP) (Nemati et al. 2017). Most of the vital factors regarding the needed specification of a proper formwork can be addressed by fabric formworks. In architectural and building construction applications fabric formwork provides a simple method of making complex double curvature forms. Thus, fabric formwork has been considered as an alternative to conventional formwork (Nemati et al. 2018). Concurrent with the development of fabric formwork, some excellent ideas have been combined with architectural concepts, and structural performance consists a part of them. In the civil engineering industry, the idea of fabric formwork has not yet found a common application. This article summarises significant studies and provides an updated review of references on the structural themes of fabric formworks over 2010 to 2019.

\footnotetext{
* Corresponding author.

E-mail addresses: Nematiuts@gmail.com (S. Nemati)

(C) 2020 Growing Science Ltd. All rights reserved. doi: $10.5267 /$ j.esm.2019.8.005
} 


\section{Review papers}

Orr et al. (2010) provided the state of the art review and a summary of design methods, previous works, experimental data and optimization processes in fabric formed beams. Veenendaal (2010) gave a brief overview of what fabric formwork technology entails as well as an overview of applications and research efforts. Also, in similar research, Veenendaal et al. (2011) studied the history of concrete casting in the fabric formwork over the past century. Pedreschi et al. (2014) presented an overview of the flexible/fabric formwork usage. Schmitz (2015) provided an updated review on the fabric formworks. Besides, Hawkins et al. (2016) provided a detailed review of fabric formwork methods for complex geometries.

\section{Feasibility studies and manufacturing methods of complex structural elements}

\subsection{Feasibility studies}

Verhaegh (2010) carried out a feasibility study on the free forms concrete segments using fabric formwork and their ability to be used in structural members such as bridges and decks. The results show the excellent ability of fabric formwork poured segments for use in structures. Veenendaal et al. (2011) conducted a feasibility studied on the casting methods of prestressed fabric formed beams and trusses using an AOP (automatic optimization process). Orr et al. (2013a) and Ibell et al. (2013) studied the feasibility of fabric formwork to create the extraordinary possibility of highly optimized architecturally concrete structures. Also, Feng et al. (2013) described the feasibility of marine application of fabric formworks. Schipper and Grünewald (2014) studied and demonstrated the ecological feasibility of an innovative production system to produce double-curved building shapes using flexible formworks. Lee et al. (2015) conducted feasibility and constructability study of free-form concrete structures considering time, cost, quality and safety. Also, Schipper (2015) studied on fabric formworks and technical notes of the flexible formwork method to build the double-curved precast structural concrete elements during his doctoral degree thesis. He showed that flexible formworks are suitable for double-curved concrete members.

\subsection{Manufacturing methods}

West (2016) provided a comprehensive handbook on flexible formworks technology. He provided a guidance for model and design of fabric-formed structures. Christian et al. (2010) described a digitally controlled formwork for double-curved surfaces using digital CAD model. Schipper and Janssen (2011) studied construction methods of double-curved pre-constructed panels using fabric/flexible formwork. They reported on the structural models that have been developed to describe the behavior of flexible formwork material accurately. Orr et al. (2011a) and Orr (2012) have presented the practical points of use and construction methods of non-orthogonal fabric formed structural elements. In a co-conception research, (Pedreschi et al. 2011, Pedreschi 2013) presented the outcome of a prolonged series of studies on the construction of fabric formworks. Also, Orr et al. (2012a) studied ultra-high performance fiber reinforced concrete elements construction methods using fabric formwork. Belton (2012) studied the tensile membranes as flexible formwork using digital tools. His work demonstrated a process of a fast and economic system to design and construction of geometrical complex cast in place structures. Cauberg et al. (2012) studied construction methods of doubly curved shell elements using textile reinforced concrete and fabric formwork. Prousalidou (2012) showed 3D scanning methods could improve the efficiency/accuracy of prediction the cast material behavior based on geometric principles and the type of fabric. Bhooshan and El Sayed (2012) presented a customised designer-friendly workflow using subdivision surfaces and attempts to construct two shell proto-types so designed with different formwork methods, fabric, and waffle. They subsequently compared the benefits and challenges of both. Hawkswood (2012) described the various aspects of fabric formwork technology and systems used in marine construction. Verwimp et al. (2014) presented the analysis and constructing method of TRC (textile reinforced cement) composites formwork and TRC reinforcement of synclastic concrete shells under their self-weight. They showed that local buckling is the critical parameter for the TRC thickness. 
Spadea et al. (2015) attempted to completely replace the internal steel reinforcement of concrete beams with fiber-reinforced polymer (FRP) reinforcement. They explained the consideration of the manufacturing steps, construction methods, and structural design requirements. Culver et al. (2016) presented an economical workflow realizing a network of parametric geometry using a roboticallycontrolled system for fabric formworks. They considered the material limitation, structural properties, and optimized load-path to provide a digitally informed geometry. Also, Yang et al. (2018) presented a new fabric formwork system to work in conjunction with a 6-axis robotic arm for casting doubly curved structural panels. Liew et al. (2018) described a prototype rod-fabric system, including the fabrication, shape control, and measurement of the nodal coordinates via theodolite. Table 1, summarizes the previous works in this regard.

Table 1. Feasibility studies and manufacturing methods of complex structural elements

\begin{tabular}{|c|c|}
\hline Ref. & Investigated parameters \\
\hline Verhaegh (2010) & - free forms concrete segments behavior \\
\hline Christian et al. (2010) & - $\operatorname{cost}$ \\
\hline Veenendaal et al. (2011) & - interaction of prestressed fabric and wet concrete \\
\hline Schipper and Janssen (2011) & - $\quad$ structural mechanics models \\
\hline Orr et al. (2011a) & - construction methods \\
\hline Pedreschi et al. (2011) & $\begin{array}{ll}\text { - } & \text { surface texture } \\
\text { - } & \text { design methods } \\
\text { - } & \text { development and construction methods } \\
\text { - } & \text { structural tests }\end{array}$ \\
\hline Orr (2012) & - construction methods \\
\hline Orr et al. (2012a) & - $\quad$ methods for manufacturing ultra-high performance fiber reinforced concrete elements \\
\hline Belton (2012) & - $\quad$ application of actively tensile membranes as formwork \\
\hline Cauberg et al. (2012) & - $\quad$ shell elements of TRC \\
\hline Prousalidou (2012) & - the behavior of cast material \\
\hline Bhooshan and El Sayed (2012) & - $\quad$ customized workflow \\
\hline Hawkswood (2012) & - different aspects of fabric formwork systems used in marine construction \\
\hline Pedreschi (2013) & $\begin{array}{ll}\text { - } & \text { surface texture } \\
\text { - } & \text { design methods } \\
\text { - } & \text { development and construction methods } \\
\text { structural tests }\end{array}$ \\
\hline Orr et al. (2013) & - $\quad$ optimized architecturally concrete structures \\
\hline Ibell et al. (2013) & - $\quad$ optimized architecturally concrete structures \\
\hline Feng et al. (2013) & - marine application \\
\hline Schipper and Grünewald (2014) & - ecological potential \\
\hline Verwimp et al. (2014) & - construction of synclastic concrete shells using TRC composites \\
\hline Lee et al. (2015) & $\begin{array}{ll}- & \text { cost } \\
- & \text { time } \\
- & \text { quality } \\
- & \text { safety }\end{array}$ \\
\hline Schipper (2015) & - $\quad$ production methods \\
\hline Spadea et al. (2015) & $\begin{array}{l}\text { - } \quad \text { manufacturing process } \\
\text { - } \quad \text { construction methods } \\
\text { technical design requirements }\end{array}$ \\
\hline West (2016) & - instruction and guidance on modelling and design \\
\hline Culver et al. (2016) & $\begin{array}{ll}\text { - } & \text { material constraints } \\
\text { - } & \text { structural weaknesses } \\
\text { load-path optimization }\end{array}$ \\
\hline Yang et al. (2018) & - robotic casting methods \\
\hline Liew et al. (2018) & - $\quad$ spatial coordinates of the markers and the node locations \\
\hline
\end{tabular}

\section{Finite element modelling, structural optimizing and form-finding themes}

\subsection{Modelling and optimising}

Garbett et al. (2010) described how free-formed members could be optimally designed and constructed. Orr et al. ( 2011) studied optimization, design and shape prediction methods of fabric formed concrete beams. They tested two $2 \mathrm{~m}$ span beams using steel and fiber-reinforced polymer reinforcing 
bars. Results showed that both beams exceeded their design capacity and showed similar behavior at the serviceability limit state. Block Research Group (BRG) (BRG 2012) explored the fundamental analysis and design of geotextile or coated fabric made formworks. Orr et al. (2011b) and Orr (2012) presented fabric formed concrete beams shape prediction method and optimization procedure. Also, Orr et al. (2012a) illustrated some methods for the optimized design of ultra-high performance fiber reinforced concrete elements using fabric formwork and structural tests. Hashemian (2012) studied the structural behavior and optimization of reinforced concrete beams. The outcome of the final phase of this study was the creation of the third generation of curved beams with a camber. These beams, designated as Cambered Curve beams (CCBs), exhibited the same behavior as the rectangular control beam. The CCB moment-shaped beams require $20 \%$ less concrete and $40 \%$ less reinforcing steel (no shear stirrups) to carry the ultimate load, which is only $12 \%$ less than that carried by the control beam. A significant part of this research was to modify and verify a FORTRAN-based finite element analysis program: FINITY. This program was reconstructed to analyze a full-size beam and enabled the researcher to model and correctly predict the maximum load, crack pattern, and failure mode. This study found that momentshaped beams with no shear reinforcement have the same stiffness and load-carrying capacity as rectangular control beam with shear reinforcement up to serviceability failure ( $\mathrm{Span} / 360)$. The study also found that moment-shaped beams have significantly lower ductility at the ultimate load. Bak et al. (2012) presented a new methodology for the construction and design of optimized fabric formed concrete members. Orr et al. (2012b) worked on the design of fabric formed structural members and discussed the shear behavior of non-prismatic steel-reinforced concrete beams too. Also, Orr et al. (2014) presented a new optimized design system for fabric formed simple concrete beams. They achieved to material savings of up to $40 \%$, considering all limit states. They demonstrated the interdependency of design method with the construction system too. In a similar work, Sarieddine (2014) provided a method for optimization of fabric formed concrete beams design using an analytical optimization method and a feasible region method. He showed that savings of up to 55\% in material cost could be accomplished using fabric formed beams. Prayudhi et al. (2015) designed a column using topology optimization method and an unconventional fabrication method.

\subsection{Form finding}

Foster (2010) studied on a method to predict the structural behavior and the shape of fabric formed beams. Analyses, including (and neglecting) the contribution of concrete in tensile behavior are found to overestimate beam stiffness (and underestimated beam stiffness and ductility). Veenendaal and Block (2011) discussed and compare the surface stress and force density, stiffness matrix, and dynamic relaxation form-finding methods. Van Mele and Block (2011) introduced a new form-finding approach based on Thrust Network Analysis (TNA) and Force Density Method (FDM) for the design of prestressed structural flexible moulds for concrete shells. In an investigation by Hawkins et al. (2016), several small scale fabric cast concrete beams were made using 'keel mould' and 'free hanging' methods and some form-finding tools were also developed. Foster and Ibell (2016) detailed a new digital method for determining the geometry of a flexible, impermeable, and inextensible hanging fabric subject to the wet concrete hydrostatic pressure and its accuracy was determined too. Table 2 summarizes the previous works published for Finite element modeling, structural optimizing and form-finding themes.

Table 2. Finite element modelling, structural optimizing and form-finding themes

\begin{tabular}{lll}
\hline \multicolumn{1}{c}{ Ref. } & \multicolumn{1}{c}{ Investigated parameters } \\
\hline Garbett et al. (2010) & - & structural optimization \\
Foster (2010) & - & s profile of a hanging fabric container \\
& ductility \\
Veenendaal and Block (2011) & - & ftiffness matrix \\
& - & dynamic relaxation \\
Van Mele and Block (2011) & - & Force Density Method (FDM) \\
Orr et al. (2011a) & - Thrust Network Analysis (TNA) \\
Orr et al. (2011b) & - the latest methods for the design, optimization and form prediction of fabric formed concrete beams \\
\hline
\end{tabular}


Table 2. Finite element modelling, structural optimizing and form-finding themes (Continued)

\begin{tabular}{|c|c|}
\hline Ref. & Investigated parameters \\
\hline Orr (2012) & - techniques for optimization \\
\hline Orr et al. (2012a) & - methods for the design, optimization and construction \\
\hline BRG (2012) & - integral analysis and design \\
\hline Hashemian (2012) & $\begin{array}{ll}\text { - } & \text { stiffness } \\
\text { - } & \text { concrete measurement } \\
\text { - } & \text { reinforcing steel percentage } \\
\text { - } & \text { load-carrying capacity } \\
\text { - } & \text { crack pattern } \\
\text { - } & \text { dailure mode } \\
\text { ductility }\end{array}$ \\
\hline Bak et al. (2012) & $\begin{array}{l}\text { - } \quad \text { topological optimization algorithms } \\
\text { - } \quad \text { eomputational form-finding } \\
\text { - } \\
\text { manufacal shape } \\
\text { practical casting techniques }\end{array}$ \\
\hline Orr et al. (2012b) & - shear behavior of non-prismatic steel-reinforced concrete beams \\
\hline Orr et al. (2014) & $\begin{array}{l}\text { - an iterative method for the design of structurally optimized beams considering all limit states } \\
\text { - } \quad \text { reinforcement detailing } \\
\text { methods to support the flexible formwork and alternative support conditions }\end{array}$ \\
\hline Sarieddine (2014) & $\begin{array}{l}\text { - } \quad \text { analytical optimization method } \\
\text { - } \quad \text { feasible region method }\end{array}$ \\
\hline Prayudhi et al. (2015) & - $\quad$ topology optimization method \\
\hline Hawkins et al. (2016) & $\begin{array}{l}\text { - } \quad \text { free hanging method } \\
\text { - } \\
\text { keel mould method }\end{array}$ \\
\hline Foster and Ibell (2016) & - form of fabric formworks subject to the hydrostatic load \\
\hline
\end{tabular}

\section{Stay-in-place structural formworks theme}

Brennan et al. (2013) explained the potential of advanced fabric formwork to provide better structural performance and permeability. Also, dual-function permanent fabric formworks and internal woven reinforcement and cavity systems are presented. Verbruggen et al. (2013) compared a fully steel reinforced beam with a similar beam including shear reinforcement in TRC formwork. Results showed similar yielding behavior for them. Verwimp et al. (2013) have presented the structural analysis of a permanent formwork in TRC composites for concrete shells. Also, Verwimp et al. (2016) studied the numerical evaluation of structural permanent formwork in TRC composite for concrete shells. They showed formwork local buckling is the dominant factor and should drive future work towards this problem. Popescu and coworkers (Popescu et al. 2016, 2018) introduced a new formwork system as a labor and material reducing, and cost-effective way for building doubly-curved concrete members and investigated its mechanical properties experimentally. Table 3 summarizes the previous works performed on stay-in-place structural formworks theme.

Table 3. Stay-in-place structural formworks theme

\begin{tabular}{|c|c|}
\hline Ref. & Investigated parameters \\
\hline Brennan et al. (2013) & - the potential of advanced textiles for fabric formwork \\
\hline Verbruggen et al. (2013) & $\begin{array}{l}\text { - } \quad \text { yielding behavior } \\
\text { - } \\
\text { cracking moment }\end{array}$ \\
\hline Verwimp et al. (2013) & - $\quad$ structural analysis and behaviour \\
\hline Verwimp et al. (2016) & $\begin{array}{l}\text { minimum thickness of the composite formwork and } \\
\text { reinforcement } \\
\text { - local buckling of the formwork }\end{array}$ \\
\hline Popescu et al. (2016) & $\begin{array}{ll}\text { - } & \text { material saving } \\
\text { - } & \text { labor reducing } \\
\text { - } & \text { cost-effective casting }\end{array}$ \\
\hline Popescu et al. (2018) & $\begin{array}{ll}- & \text { material saving } \\
\text { - } & \text { labor reducing } \\
\text { - } & \text { cost-effective casting } \\
\end{array}$ \\
\hline
\end{tabular}




\section{Cable-net fabric formwork theme}

Torsing et al. $(2012,2015)$ studied three design cases using combined systems of cable-net formwork and geotextiles. They used physical, digital and parametric design models to imitate and inform physical realities. Veenendaal and Block (2014) explored the usage of a mixed system of cable net and fabric formworks to build large-span concrete roofs, shell structures and bridges. They showed it is possible to form a wide range of complex shapes such as hyperbolic paraboloid. On the other hand, Veenendaal et al. (2014) presented a prototype hybrid system consists of cable-net and fabric formwork to build shell structures. They were used to control more accurate methods to digital measuring both the as-built shape and internal stresses of the net. Tang et al. (2015) examined the potential to use grid-shell and fabrics as a re-deployable, recyclable, reusable and re-configurable formwork system for concrete shells. They presented the results of trial construction of two concrete shells using a grid-shell coupled with a textile membrane as formwork. Digital image control and a careful survey of the deformations were made. A detailed study of as-built geometry of the shells was compared with the initial geometry of the system. Also, Veenendaal and Block (2015) described a numerical method to design a shell roof fabric formwork system. Also, they discussed some form-finding methods to design fabric formworks. Veenendaal et al. $(2015,2017)$ described a digital method for nonlinear analysis and structural optimized design of a ferrocement sandwich shell roof using cable-net and fabric formwork. This method consists of multicriteria evolutionary optimization and evaluating several parameters such as stiffness and strength of the shell and architectural/constructional constraints. Coar et al. (2016) described the design and construction method of a cable-net fabric and ice shell system. They presented the design method, structural behavior, fabrication, construction and performance of the final shell structure using origami concepts and folded plate structures. Echenagucia et al. (2019) described the construction method of a concrete shell roof with a new cable-net and fabric formwork system. After installing the boundary structure, non-uniform calculated pre-stressing forces were applied and the cable-net was tensioned. Also, a controlling system was applied to minimize deviations between the as-built and digital geometry. Table 4 summarizes the previous works performed on cable-net fabric formwork theme.

Table 4. Cable-net fabric formwork theme

\begin{tabular}{|c|c|}
\hline Ref. & Investigated parameters \\
\hline Torsing et al. ( 2012) & - $\quad$ physical and digital, parametric design models \\
\hline Veenendaal and Block (2014) & - prestressing forces \\
\hline Veenendaal et al. (2014) & $\begin{array}{l}\text { - } \quad \text { as-built shape and internal forces of the cable net } \\
\text { - form-finding model of the cable net }\end{array}$ \\
\hline Tang et al. (2015) & - deformation \\
\hline Torsing et al. ( 2015) & - $\quad$ physical and digital, parametric design models \\
\hline Veenendaal and Block (2015) & - $\quad$ stress distributions \\
\hline Veenendaal et al. (2015) & $\begin{array}{l}\text { optimization and evaluating various parameters such as: } \\
\text { - } \quad \text { strength } \\
\text { - } \quad \text { stiffness } \\
\text { - } \quad \text { stability } \\
\text { architectural and constructional constraints }\end{array}$ \\
\hline Coar et al. (2016) & $\begin{array}{ll}\text { - } & \text { design process } \\
\text { - } & \text { structural behaviour } \\
\text { - } & \text { fabrication and construction methods } \\
\text { - } & \text { performance }\end{array}$ \\
\hline Veenendaal (2017) & $\begin{array}{l}\text { optimization and evaluating various parameters such as: } \\
\text { - } \quad \text { strength } \\
\text { - } \text { stiffness } \\
\text { - } \quad \text { stability } \\
\text { architectural and constructional constraints }\end{array}$ \\
\hline Echenagucia (et al. 2019) & $\begin{array}{l}\text { - } \quad \text { non-uniform distribution of pre-stressing forces } \\
\text { - } \quad \text { as-built geometry } \\
\text { - } \quad \text { a digital model of the form }\end{array}$ \\
\hline
\end{tabular}

\section{Pneumatic / Vacuumatic formwork theme}

Burak et al. (2010) studied on the analytical modelling of the optimum modes of concrete casting 
using pneumatic formworks. They presented an experimental-theoretical model of the technological process of fine-grained concrete mix shotcreting on horizontally located pneumatic formwork. Recoil indicator and concrete strength dependence on such parameters, as the productive capacity of shotcretemachine, the nozzle diameter, the distance from the nozzle to the formwork surface and tension of pneumatic formwork material. The comparison of theoretical dependencies and experimental ones has shown their qualitative correspondence. The flexibility control of vacuumatic / pneumatic formworks is considered by Huijben et al. (2011). They provided a creative method for building the curved concrete shells using vacuumatics formwork. Also, Huijben et al. (2012) illustrated the vacuumatic flexible formworks too. In this regard, they studied 'suspension method' and the 'lifting method' as two shape design methods. They showed vacuumatics might be used as a self-supporting formwork structure to build any curved concrete modulus with any surface textures. Kromoser (2012) used also pneumatic formworks for shaping and erecting the ice shell structures with double curvature. Van et al. (2013) and Pronk et al. (2013a,b) studied and tested the best combination of construction, material, and typology of three-dimensional fabric formed bending structures. The results of full-scale modeling illustrated the designed structure is $40 \%$ lighter as conventional beams of the same material. Kromoser and Kollegger (2015 a,b) introduced the different application of pneumatic formworks to build concrete doublecurvature shells. Non-linear finite element calculations, tensile, bending, and bonding tests were used to determine the best combination of concrete and reinforcement. Pronk et al. (2015) studied on design and construction methods of five ice domes using an inflatable formwork and sprayed water, snow and fiberreinforced ice (pykrete) to create a pykrete shell at $-8^{\circ} \mathrm{C}$ or lower. In a similar work, Pronk et al. (2016) studied on the reinforced ice structures using an inflatable mould. They reinforced the ice by cellulose as fiber material. Therefore, the material would be twenty times more ductile and three times stronger than ordinary ice. The reinforced ice shells are made by spraying layers of fiber-reinforced ice on an inflatable formwork. The inflatable formwork was designed to achieve minimum deformation and optimal force distribution. Kromoser and Huber (2016) also explained the application of most important pneumatic formwork systems and presented a novel construction method, called "Pneumatic Forming of Hardened Concrete (PFHC)." Kostova et al. (2016) demonstrated the possibility to build FRP-reinforced fabric formed beams exhibiting ductile behaviour using experimental tests. They presented construction approaches and design methodology too.

Table 5. Pneumatic / Vacuumatic formwork theme

\begin{tabular}{|c|c|}
\hline Ref. & $\begin{array}{ll}\text { Investigated parameters } \\
\end{array}$ \\
\hline Burak et al. (2010) & $\begin{array}{l}\text { Recoil indicator and concrete strength dependence on: } \\
\text { - the productive capacity of shotcrete-machine } \\
\text { - the nozzle diameter } \\
\text { - the distance from the nozzle to the formwork surface } \\
\text { the tension of pneumatic formwork material }\end{array}$ \\
\hline Huijben et al. (2011) & - constructing consideration of vacuumatics formworks \\
\hline Huijben et al. (2012) & $\begin{array}{ll}\text { - } & \text { suspension method } \\
\text { - } & \text { lifting method }\end{array}$ \\
\hline Kromoser (2012) & - ice shell construction method \\
\hline Van de Koppel et al. (2013) & - $\quad$ optimized inflatable beams \\
\hline Pronk et al. (2013a) & - $\quad$ optimized inflatable beams \\
\hline Pronk et al. (2013b) & - $\quad$ optimized inflatable beams \\
\hline Kromoser and Kollegger (2015a) & $\begin{array}{l}\text { - } \quad \text { non-linear finite element calculations } \\
\text { - } \quad \text { bensile tests } \\
\text { - } \quad \text { bonding tests } \\
\text { bonds test }\end{array}$ \\
\hline Kromoser and Kollegger (2015b) & $\begin{array}{l}\text { - } \quad \text { non-linear finite element calculations } \\
\text { - } \quad \text { bensile tests } \\
\text { - } \quad \text { bonding tests } \\
\text { bests }\end{array}$ \\
\hline Pronk et al. (2015) & - Ice structures construction method \\
\hline Pronk et al. (2016) & - Ice structures construction method \\
\hline Kromoser and Huber (2016) & - $\quad$ construction method \\
\hline Kostova et al. (2016) & - ductility \\
\hline Abramyan, et al. (2017) & $\begin{array}{ll}\text { - } & \text { design method } \\
\text { - } & \text { installation techniques } \\
\text { - } & \text { dismantling techniques }\end{array}$ \\
\hline Coar et al. (2018) & - $\quad$ construction method \\
\hline
\end{tabular}


Abramyan et al. (2017) described the design, installation, and dismantling techniques of a reusable multipurpose mobile pneumatic rubber-fabric formwork systems. They showed that installation and dismantling of such formworks are much easier than conventional formworks. Coar et al. (2018) introduced a bending frame to make a fabric formed ice shell. They presented a novel construction method to establish a reliable link between numeric optimization design methods and the often incongruent realities that must be confronted to build such a structure. The previous works performed on the pneumatic/vacuumatic formwork theme has been summarized in Table 5.

\section{Durability, sustainability, efficiency and quality improvement}

Delijani (2010) and Delijani et al. (2015) investigated and documented the changes in concrete quality and strength due to the use of woven polyolefin fabrics by two sets of tests. Variables in this study were types of fabric permeability and types of concrete. They used normal concrete (NC) and concrete with $30 \%$ fly ash (FAC). The test results showed that the influence of fabric formwork on concrete quality is limited mostly to the surface zone. Fabric formed cylinder tests showed about $15 \%$ improvement in compressive strength. The compressive strength of the reinforced columns did not significantly change when compared to the cardboard formed columns. Orr et al. $(2010,2011 \mathrm{c})$ used fully and partially resincoated carbon fiber reinforced polymer (CFRP) grids instead of the conventional steel stirrups as shear reinforcement. Results showed good behaviour for the presented system. Lee (2011) concentrated in improved material quality, through a creative construction system of flexible fabric formwork for a reinforced concrete beam. In this regard, eleven types of beams have been built and tested and their construction methods are described. The analysis shows that the total embodied energy of the fabric formed beam is about $20 \%$ to $40 \%$ less in comparison with the conventionally designed beams. Orr et al. (2012b, 2016) studied the application of fabric formworks in the optimised structural elements. They demonstrated that the use of fabric formwork construction system might provide a sustainable, economic and durable concrete structures. Kostova et al. (2012) examined the advantages of using advanced fiber reinforced polymer bars for construction and design of fabric-formed concrete beams. Gass or carbon fiber reinforced polymer reinforcing bars could solve the existing problem of concrete cover due to their corrosion resistance. Also, using non-corrodable reinforcement offers a possibility to reduce the carbon footprint of fabric-formed structures by replacing the OPC (ordinary Portland cement) with low carbon concrete types. Kostova et al. (2013) studied on the structural behaviour of optimised fabric-formed beams reinforced with glass and carbon FRP bars. Other important aspects related to the structural design and predictability of deflections, such as the construction accuracy, are also examined. Also, Orr et al. (2013) using accelerated test methods demonstrated considerable durability advantages for fabric formed concrete as $50 \%$ reductions in the non-steady state chloride diffusion and carbonation coefficients. Surface hardness and scanning electron microscopy tests demonstrated further benefits too. In order to build concrete panels and exterior cladding systems in buildings, Sprague (2014) assessed the influence of a flexible formwork on the compressive strength of concrete formed with different types of membranes. Results showed that the permeable membrane formwork produced a higher strength concrete.

Pedreschi (2015) studied the effect of shape on the compressive strength of non-prismatic columns using fabric formworks. Results showed the convex columns carried the least load, and the concave columns sustained the most significant load approximately $90-100 \%$ stronger in some cases. Xiong and Mashiur (2016) investigated stitching and laminating methods to reinforce glass yarns in a woven polyethylene (PE) geotextile fabric formwork. Creep investigation showed stitching method provides better tensile behaviour than the laminating method. Menez (2016) studied fabric formed concrete slabs. He compared its material, carbon energy, and cost savings with a common reinforced concrete flooring system. He showed not only the weight of this slab could be reduced by about $50 \%$ but also, the embodied carbon footprint of the entire building could be decreased by about $50 \%$. Ioannou et al. (2016) studied on the durability of fabric formed super sulphated concrete. The study was included a comparison of water absorption rate, chloride resistance, carbonation resistance and $\mathrm{pH}$ values. Results showed fabric 
formwork minimised the pore volume near the surface, maintained the $\mathrm{pH}$ values at higher-profile depths and better durability. Also, carbonation depths were decreased by about $35 \%$, and absorption rates were found to be about $40 \%$ lower. Table 6 , provides a summarized review of published works in this regard.

Table 6. Durability, sustainability, efficiency, and quality improvement

\begin{tabular}{|c|c|}
\hline Ref. & Investigated parameters \\
\hline Delijani (2010) & $\begin{array}{l}\text { - compressive strength of fabric formed concrete } \\
\text { - the behavior of the fabric formed reinforced columns }\end{array}$ \\
\hline Orr et al. (2010) & - $\quad$ steel corrosion and durability \\
\hline Orr et al. (2011a) & - $\quad$ steel corrosion and durability \\
\hline Lee $(2011)$ & - $\quad$ total embodied energy \\
\hline Orr et al. (2012) & $\begin{array}{ll}\text { - } & \text { durability } \\
\text { - } & \text { visual benefits }\end{array}$ \\
\hline Kostova et al. (2012) & - durability \\
\hline Kostova et al. (2013) & - deflections \\
\hline Orr et al. (2013) & - durability \\
\hline Sprague (2014) & $\begin{array}{l}\text { - } \quad \text { compressive strength of concrete } \\
\text { - } \quad \text { surface properties }\end{array}$ \\
\hline Pedreschi (2015) & $\begin{array}{l}\text { - } \quad \text { compressive strength } \\
\text { - lateral tensile strains }\end{array}$ \\
\hline Delijani et al. (2015) & $\begin{array}{l}\text { - compressive strength of fabric formed concrete } \\
\text { - the behavior of the fabric formed reinforced columns }\end{array}$ \\
\hline Orr et al. (2016) & $\begin{array}{ll}\text { - } & \text { durability } \\
\text { - } & \text { visual benefits }\end{array}$ \\
\hline Xiong and Mashiur (2016) & - $\quad$ tensile properties \\
\hline Menez (2016) & $\begin{array}{ll}\text { - } & \text { efficiency of material } \\
\text { - } & \text { carbon energy } \\
\text { - } & \text { cost }\end{array}$ \\
\hline Ioannou et al. (2016) & $\begin{array}{ll}\text { - } & \text { chloride resistance } \\
\text { - } & \text { carbonation resistance } \\
\text { - } & \text { pH values } \\
\text { - } & \text { water absorption }\end{array}$ \\
\hline
\end{tabular}

\section{Results and conclusion}

According to the above comprehensive discussion, the following conclusions can be found:

- The references on the structural performance of fabric formworks over the last decade could be categorised into seven themes; namely, "Feasibility studies and manufacturing methods of complex structural elements"; "Finite element modelling, structural optimizing and form-finding themes"; "Pneumatic / Vacuumatic formwork theme"; "Durability, sustainability, efficiency and quality improvement"; "Cable-net fabric formwork theme"; "Stay-in-place structural formworks theme"; and "Review papers". These categories comprise about $25 \%, 17 \%, 15 \%, 15 \%, 10 \%, 6 \%$ and $6 \%$ of related studies respectively (Fig. 1).

\footnotetext{
- Feasibility studies and manufacturing methods of complex structural elements

- Finite element modeling, structural optimizing and form finding themes

- Pneumatic / Vacuumatic formwork theme

- Durability, sustainability, efficiency and quality improvement

- Cable-net fabric formwork theme

Review papers
}

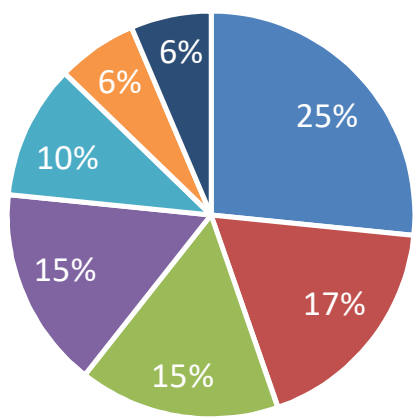

Fig. 1. The percentage of research themes regarding the structural points of view on the fabric formworks (2010 - Jul 2019) 
- The number of researches regarding the structural performance of the fabric formworks over the last decade is shown in Fig. 2.

- There are some suitable construction methods for double-curved preconstructed panels using fabric/flexible formwork.

- Nowadays, ultra-high performance fibre reinforced concrete elements construction methods using fabric formwork are used for geometrical complex structures.

- Using 3D scanning methods, the accuracy and efficiency of prediction the cast material behavior would be improved.

- Fabric formwork technology and systems are used in marine construction perfectly.

- Highly optimized architecturally concrete structures can be created by fabric formworks.

- Use of fabric formwork can improve the durability and quality of concrete structures.

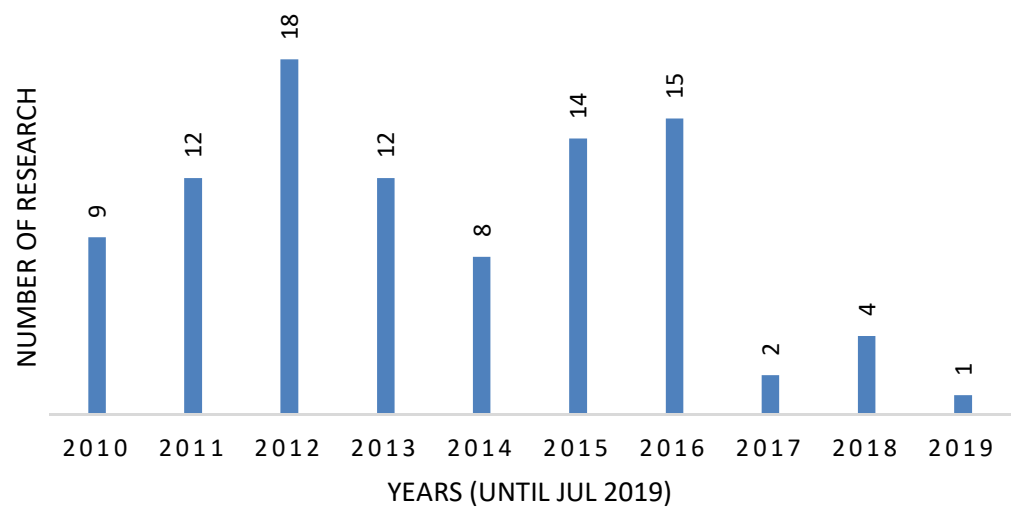

Fig. 2. The number of researches regarding the structural points of view on the fabric formworks (2010 - Jul 2019)

\section{References}

Abramyan, S., Polyakov, V., \& Oganesyan, O. (2017). Pneumatic formwork used in strengthening of structural elements during reconstruction of buildings and structures. In MATEC Web of Conferences (Vol. 129, p. 05001). EDP Sciences.

Bak, A., Shepherd, P., \& Richens, P. (2012, June). Intuitive interactive form finding of optimised fabric-cast concrete. In Second International Conference on Flexible Formwork (icff2012). University of Bath.

Belton, S. (2012). The application of actively tensioned membranes as formwork for complex curvatures in concrete structures. WIT Transactions on The Built Environment, 124, 27-38.

Benjamin Kromoser, J. K. (2012). Using Ice to Build Shell Structures. 10th International Conference and Exhibition on Performance of Ships and Structures in Ice 2012, ICETECH 2012. Banff, AB; Canada: 403410.

Bhooshan, S., \& El Sayed, M. (2012). Sub-division surfaces in architectural form finding and fabric forming. In Proceedings of the Second International Conference of Flexible Formwork (ICFF 2012), BRE CICM, University of Bath, Claverton Down.

Brennan, J., Pedreschi, R., Walker, P., \& Ansell, M. (2013). The potential of advanced textiles for fabric formwork. Institute of Civil Engineering (ICE)-Construction Materials Journal, 166(4), 229-237..

BRG (2012). Computational modelling of fabric formwork. 2nd International Conference on Flexible Formworks.

Burak, E. E., Loboda, A. V., \& Tkachenko, A. N. (2010). MATHEMATICAL MODELING OF THE OPTIMUM MODES OF CONCRETING WITH THE USE OF PNEUMATIC FORMWORK. Scientific Herald of the Voronezh State University of Architecture and Civil Engineering. Construction and Architecture, (4), 64-75.

Cauberg, N., Tysmans, T., Adriaenssens, S., Wastiels, J., Mollaert, M., \& Belkassem, B. (2012). Shell elements of textile reinforced concrete using fabric formwork: a case study. Advances in Structural Engineering, 15(4), 677-689. 
Jepsen, C. R., Kristensen, M. K., \& Kirkegaard, P. H. (2010). Flexible mould for precast concrete elements. In International Symposium of the International Association for Shell and Spatial Structures: IASS 2010 (pp. 2726-2737). China Architecture \& Building Press..

Coar, L., Cox, M. S., \& Adriaenssens, S. M. (2018). Seeking congruency in digital optimisation and constructability in fabric formed ice shells utilising bending active frames. International Journal of Rapid Manufacturing, 7(2-3), 186-202.

Coar, L., Mueller, C., Laet, L. D., Hare, J., Wiese, K., \& Oberlin, S. (2016, September). Fabrigami: Design and fabrication of an origami-inspired ice and fabric shell. In Proceedings of IASS Annual Symposia (Vol. 2016, No. 1, pp. 1-10). International Association for Shell and Spatial Structures.

Culver, R., Koerner, J., \& Sarafian, J. (2016). Fabric Forms: The Robotic Positioning of Fabric Formwork. In Robotic Fabrication in Architecture, Art and Design 2016 (pp. 106-121). Springer.

Delijani, F. (2010). The evaluation of changes in concrete properties due to fabric formwork.

Delijani, F., West, M., \& Svecova, D. (2015). The evaluation of change in concrete strength due to fabric formwork. Journal of Green Building, 10(2), 113-133.

Echenagucia, T. M., Pigram, D., Liew, A., Van Mele, T., \& Block, P. (2019, April). A cable-net and fabric formwork system for the construction of concrete shells: Design, fabrication and construction of a full scale prototype. In Structures (Vol. 18, pp. 72-82). Elsevier.

Feng, Q., Wu, X. G., \& Zhao, B. D. (2013). Study and Application of Permeability Formwork to Marine Concrete. In Applied Mechanics and Materials (Vol. 438, pp. 333-337). Trans Tech Publications.

Foster, R. (2010). Form finding and analysis of fabric formed concrete beams.

Foster, R. M., \& Ibell, T. J. (2016, November). A numerical solution for the shape of fabric-formed concrete structures. Structures, 8, 17-24.

Garbett, J., Darby, A. P., \& Ibell, T. J. (2010). Optimised beam design using innovative fabric-formed concrete. Advances in Structural Engineering, 13(5), 849-860.

Hashemian, F. K. (2012). Structural behaviour and optimization of moment-shaped reinforced concrete beams, University of Manitoba (Canada).

Hawkins, W., Orr, J., Shepherd, P., \& Ibell, T. (2016). Fabric formed concrete: physical modelling for assessment of digital form finding methods.

Hawkins, W. J., Herrmann, M., Ibell, T. J., Kromoser, B., Michaelski, A., Orr, J. J., ... \& Veenendaal, D. (2016). Flexible formwork technologies-a state of the art review. Structural Concrete, 17(6), 911-935.

Hawkswood, M. G. (2012). Fabric formwork systems used in marine construction. Proceedings of The Second International Conference on Flexible Formwork, University of Bath, UK.

Huijben, F., Van Herwijnen, F., \& Nijsse, R. (2011, December). Concrete Shell Structures Revisited: Introducing A New 'Low-Tech'Construction Method Using Vacuumatics Formwork. In Structural Membranes 2011: V International Conference on Textile Composites and Inflatable Structures.

Huijben, F., van Herwijnen, F., \& Nijsse, R. (2012). 14 Structural Morphology of VACUUMATICS 3D Formwork Systems: Constructing Thin Concrete Shells with 'Nothing'. In conference; 2nd International Conference on Flexible Formwork; 2012-06-27; 2012-06-29 (pp. 154-163). University of Bath.

Ibell, T., Orr, J., Kostova, K., Darby, A., \& Evernden, M. (2013). Extraordinary possibilities for future concrete structures. The IES Journal Part A: Civil \& Structural Engineering, 6(4), 239-248.

Ioannou, S., Badr, A., Kostova, K., Paine, K., \& Ibell, T. (2016). Utilization of fabric formwork for improving the durability of concrete from supersulfated cement. In Key Engineering Materials (Vol. 711, pp. 615621). Trans Tech Publications.

Kostova, K., Ibell, T. J., Darby, A. P., \& Evernden, M. (2012, June). Advanced composite reinforcement for fabric-formed structural elements. In Second International Conference on Flexible Formwork (icff2012) (pp. 200-210). The BRE Centre for Innovative Construction Materials.

Kostova, K. Z., Ibell, T. J., Darby, A. P., \& Evernden, M. C. (2013, December). Behaviour of fabric-formed concrete beams reinforced with FRP bars. In Advanced Composites in Construction 2013, ACIC 2013Conference Proceedings (pp. 286-297).

Kostova, K., Ibell, T., Darby, A., \& Evernden, M. (2016, August). Using fabric to shape appropriate concrete structures. In Proceedings of the Fourth Conference on Sustainable Construction Materials and Technologies SCMT4(p. S174).

Kromoser, B., \& Huber, P. (2016). Pneumatic formwork systems in structural engineering. Advances in Materials Science and Engineering, 2016. 
Kromoser, B., \& Kollegger, J. (2015). Application areas for pneumatic forming of hardened concrete. Journal of the International Association for Shell and Spatial Structures, 56(3), 187-198.

Kromoser, B., \& Kollegger, J. (2015). Pneumatic forming of hardened concrete-building shells in the 21st century. Structural Concrete, 16(2), 161-171.

Lee, D., Hong, W. K., Kim, J. T., \& Kim, S. (2015). Conceptual study of production technology of free-form concrete segments. International Journal of Engineering and Technology, 7(4), 321.

Lee, S. H. (2011). Study of construction methodology and structural behaviour of fabric-formed formefficient reinforced concrete beam.

Liew, A., Stürz, Y. R., Guillaume, S., Van Mele, T., Smith, R. S., \& Block, P. (2018). Active control of a rod-net formwork system prototype. Automation in Construction, 96, 128-140.

Menez, M. H. (2016). Efficiency of a fabric formed concrete slab (Doctoral dissertation, Massachusetts Institute of Technology).

Nemati, S., Rashidi, M., \& Samali, B. (2017). Decision making on the optimised choice of pneumatic formwork textile for foam-filled structural composite panels. International Journal of GEOMATE 13(39), 220-228.

Nemati, S., Sharafi, P., Samali, B., Aliabadizadeh, Y., \& Saadati, S. (2018). Non-reinforced foam filled modules for rapidly assembled post disaster housing. International Journal of Geomate, 14(45), 151-161.

Orr, J. (2012). Flexible formwork for concrete structures.

Orr, J., Darby, A., Ibell, T., \& Evernden, M. (2011). Fibre reinforced polymer grids as shear reinforcement in fabric formed concrete beams.

Orr, J. J., Darby, A. P., Ibell, T. J., \& Evernden, M. C. (2011b). Innovative reinforcement for fabric formed concrete structures.

Orr, J. J., Darby, A. P., Ibell, T. J., Evernden, M. C., \& Otlet, M. (2011c) Concrete structures using fabric formwork. The Structural Engineer, 89 (8). pp. 20-26.

Orr, J. J., Darby, A., Ibell, T. J., \& Evernden, M. (2012a). Optimisation and durability in fabric cast'Double T'beams..

Orr, J., Darby, A., Ibell, T., Evernden, M., \& Otlet, M. (2012, September). Design of innovative fabric formed beams in shear. In IABSE Congress Report (Vol. 18, No. 15, pp. 1041-1048). International Association for Bridge and Structural Engineering.

Orr, J., Darby, A., Ibell, T., \& Evernden, M. (2012c). Fabric formwork for ultra high performance fibre reinforced concrete structures.

Orr, J., Darby, A., Ibell, T., \& Evernden, M. (2013). Durability enhancements using fabric formwork. Magazine of Concrete Research, 65(20), 1236-1245.

Orr, J. J., Ibell, T. J., \& Darby, A. P. (2010). Innovative concrete structures using fabric formwork. Advances and Trends in Structural Engineering, Mechanics and Computation, 234.

Orr, J., Ibell, T., Darby, A., \& Evernden, M. (2010). Fibre reinforced polymer reinforcement for fabric formed concrete structures. FRP International, 7(1), 4-5.

Orr, J. J., Ibell, T. J., Darby, A. P., \& Evernden, M. (2013). Extraordinary possibilities using fabric to form concrete structures. In Research and Applications in Structural Engineering, Mechanics and Computation (pp. 327-328). CRC Press.

Orr, J., Spadea, S., \& Miranda, H. (2016). Innovative construction using flexible moulds." Advances in Concrete Technology, Materials \& Contruction Practices (CTMC).

Orr, J. J., Darby, A., Ibell, T., \& Evernden, M. (2014). Design methods for flexibly formed concrete beams. Proceedings of the Institution of Civil Engineers-Structures and Buildings, 167(11), 654-666.

Pedreschi, R. (2013). Fabric formed concrete structures and architectural elements. Proceedings of Structures and Architecture: New concepts, applications and challenges. ICSA 2013 Second International Conference on Structures and Architecture, Guimarães, Portugal.

Pedreschi, R. (2015, August). A preliminary study of the strength of non-prismatic columns using fabric formwork. In Proceedings of IASS Annual Symposia (Vol. 2015, No. 1, pp. 1-12). International Association for Shell and Spatial Structures (IASS).

Pedreschi, R. (2011). The use of fabrics as formwork for concrete structures and elements. In International conference on textile composites and inflatable structures, Structural Membranes, Barcelona. 
Pedreschi, R. E. M. O., \& Lee, D. S. (2014). Structure, form and construction. Fabric formwork for concrete. In Across: Architectural Research through to Practice: 48th International Conference of the Architectural Science Association 2014 (pp. 99-110). The Architectural Science Assocation.

Popescu, M., Reiter, L., Liew, A., Van Mele, T., Flatt, R. J., \& Block, P. (2018, June). Building in concrete with an ultra-lightweight knitted stay-in-place formwork: prototype of a concrete shell bridge. In Structures (Vol. 14, pp. 322-332). Elsevier.

Popescu, M., Rippmann, M., Mele, T. V., \& Block, P. (2016, September). Complex concrete casting: Knitting stay-in-place fabric formwork. In Proceedings of IASS Annual Symposia(Vol. 2016, No. 7, pp. 1-9). International Association for Shell and Spatial Structures (IASS).

Prayudhi, B., Borg Costanzi, C., \& Van Baalen, S. (2015). Less material, more design-Optimized concrete structures with fabric formwork.

Pronk, A., Arntz, M., \& Hermens, L. (2016, September). Da Vinci's Bridge in ice and other ice structures with an Inflatable mould. In Proceedings of IASS Annual Symposia (Vol. 2016, No. 2, pp. 1-8). International Association for Shell and Spatial Structures (IASS).

Pronk, A. D. C., Dominicus, M. M. T., Buelow, P. V., van Dijck, S. H. M., \& van de Koppel, W. J. (2013, September). Rigidized inflatable structures a production method for optimized structures. In Proceedings of IASS Annual Symposia (Vol. 2013, No. 10, pp. 1-8). International Association for Shell and Spatial Structures (IASS).

Pronk, A. D. C., Dominicus, M. M. T., Von Buelow, P., Van Dijck, S. H. M., \& Van de Koppel, W. J. (2013, October). Producing optimized structures with inflatables structural membranes 2013. In 6th International Conference on Textile Composites and Inflatable Structures (Structural Membranes 2013), October 9-11, 2013, Munich, Germany.

Pronk, A. D. C., Verberne, T. H. P., Kern, J., \& Belis, J. (2015, August). The calculation and construction of the highest ice dome-the Sagrada Familia in Ice. In Proceedings of IASS Annual Symposia (Vol. 2015, No. 1, pp. 1-13). International Association for Shell and Spatial Structures (IASS).

Prousalidou, E. (2012). A Digital Model for Fabric Formwork Panels: Using Physical Data to Train the Digital Model.

Sarieddine, M. (2014). Optimal design of fabric formed concrete beams (Doctoral dissertation, Massachusetts Institute of Technology).

Schipper, H. R. (2015). Double-curved precast concrete elements: Research into technical viability of the flexible mould method.

Schipper, H. R., \& Grünewald, S. (2014). Efficient material use through smart flexible formwork method. In ECO-Crete: International Symposium on Environmentally Friendly Concrete, Reykjavik, Iceland, 1315 August 2014.

Schipper, H. R., \& Janssen, B. (2011). Manufacturing double curved precast concrete panels. Concrete Plant International, 4, 32-38.

Schmitz, R. P. (2015). Fabric forms for architectural concrete: A state-of-the-art report. In AEI 2015 (pp. 259268).

Spadea, S., Orr, J., \& Yang, Y. (2015, August). Bespoke Reinforcement for Optimised Concrete Structures. In Proceedings of IASS Annual Symposia (Vol. 2015, No. 1, pp. 1-8). International Association for Shell and Spatial Structures (IASS).

Sprague, C. L. (2014). Building envelope membrane as flexible formwork for concrete panels. Massachusetts Institute of Technology.

Tang, G., \& Pedreschi, R. (2015, August). Deployable gridshells as formwork for concrete shells. In Proceedings of IASS Annual Symposia (Vol. 2015, No. 1, pp. 1-12). International Association for Shell and Spatial Structures (IASS).

Torsing, R., Bakker, J., Jansma, R., \& Bhattacharya, A. (2015). Re-inventing mixed fabric and cable-net formed morphology in practice. Next Generation Building, 2(1), 91-110.

Torsing, R., Bakker, J., Jansma, R., \& Veenendaal, D. (2012). Large-scale designs for mixed fabric and cable net formed structures. In Proceedings of the 2nd international conference on flexible formworks, Bath, UK. http://www. block. arch. ethz. ch/brg/project/hilo-research-innovation-unit-nest.

Pronk, A. D. C., Dominicus, M. M. T., Buelow, P. V., van Dijck, S. H. M., \& van de Koppel, W. J. (2013, September). Rigidized inflatable structures a production method for optimized structures. In Proceedings 
of IASS Annual Symposia (Vol. 2013, No. 10, pp. 1-8). International Association for Shell and Spatial Structures (IASS).

Van Mele, T., \& Block, P. (2011). A novel form finding method for fabric formwork for concrete shells. Journal of the International Association for Shell and Spatial Structures, 52(4), 217-224.

Veenendaal, D. (2010, June). Fabric Formwork: The State-of-the-Art and Future Endeavors. In Reader Symposium TU Delft 15 juni 2010 (p. 7).

Veenendaal, D., Bakker, J., \& Block, P. (2015, August). Structural design of the cable-net and fabric formed, ferrocement sandwich shell roof of NEST HiLo. In Proceedings of IASS Annual Symposia (Vol. 2015, No. 28, pp. 1-12). International Association for Shell and Spatial Structures.

Veenendaal, D., Bezbradica, M., Novák, D., \& Block, P. (2014, September). Controlling the geometry and forces of a hybrid cable-net and fabric formwork for thin concrete shells. In Proceedings of IASS Annual Symposia (Vol. 2014, No. 15, pp. 1-8). International Association for Shell and Spatial Structures (IASS).

Veenendaal, D., \& Block, P. (2011). A framework for comparing form finding methods. Proceedings of the International Association for Shell and Spatial Structures (IABSE-IASS) Symposium.

Veenendaal, D., \& Block, P. (2014). Design process for prototype concrete shells using a hybrid cable-net and fabric formwork. Engineering structures, 75, 39-50.

Veenendaal, D., \& Block, P. (2015, August). Design process of prestressed membrane formworks for thinshell structures. In Proceedings of IASS Annual Symposia (Vol. 2015, No. 1, pp. 1-12). International Association for Shell and Spatial Structures (IASS).

Veenendaal, D., Coenders, J., Vambersky, J., \& West, M. (2011). Design and optimization of fabric-formed beams and trusses: evolutionary algorithms and form-finding. Structural Concrete, 12(4), 241-254.

Veenendaal, D., West, M., \& Block, P. (2011). History and overview of fabric formwork: using fabrics for concrete casting. Structural Concrete, 12(3), 164-177.

Veenendaal, D., Bakker, J., \& Block, P. (2017). Structural design of the flexibly formed, mesh-reinforced concrete sandwich shell roof of NEST Hilo. Journal of the International Association for Shell and Spatial Structures, 58(1), 23-38.

Verbruggen, S., Remy, O., Wastiels, J., \& Tysmans, T. (2013). Stay-in-place formwork of TRC designed as shear reinforcement for concrete beams. Advances in Materials Science and Engineering, 2013.

Verhaegh, R. R. (2010). Free forms in concrete: the fabrication of free-form concrete segments using fabric formwork.

Verwimp, E., Tysmans, T., \& Mollaert, M. (2013, September). Flexible formwork as reinforcement for curved concrete structures. In Proceedings of IASS Annual Symposia (Vol. 2013, No. 1, pp. 1-10). International Association for Shell and Spatial Structures (IASS).

Verwimp, E., Tysmans, T., \& Mollaert, M. (2014). Reinforcing concrete shells with cement composite stayin-place formwork: numerical analysis of a case study. High Performance and Optimum Design of Structures and Materials, 137, 213.

Verwimp, E., Tysmans, T., \& Mollaert, M. (2016). Numerical evaluation of structural stay-in-place formwork in textile reinforced cement composite for concrete shells. Advances in Structural Engineering, 19(9), $1500-1513$.

West, M. (2016). The Fabric Formwork Book: Methods for Building New Architectural and Structural Forms in Concrete, Routledge.

Xiong, J., \& Mashiur, R. (2016). Mechanical property measurement and prediction using Hirsch's model for glass yarn reinforced polyethylene composite fabric formwork. J. Text. Sci. Eng, 6, 241-250.

Yang, X., Loh, P., \& Leggett, D. (2019). Robotic variable fabric formwork. Journal of Computational Design and Engineering, 6(3), 404-413.

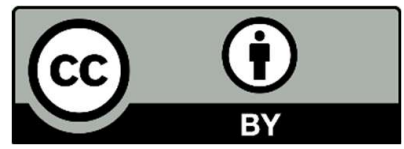

(C) 2020 by the authors; licensee Growing Science, Canada. This is an open access article distributed under the terms and conditions of the Creative Commons Attribution (CC-BY) license (http://creativecommons.org/licenses/by/4.0/). 